\title{
Fluxional Amine Gold(III) Complex as Excellent Catalyst and Precursor of Biologically Active Acyclic Carbenes
}

\author{
Sara Montanel-Pérez, ${ }^{a}$ Raquel P. Herrera, ${ }^{b}$ Antonio Laguna, ${ }^{a}$ M. Dolores \\ Villacampa ${ }^{\mathrm{a}, *}$ and M. Concepción Gimeno ${ }^{\mathrm{a}, *}$
}

\begin{abstract}
A new amine gold(III) complex $\left[\mathrm{Au}\left(\mathrm{C}_{6} \mathrm{~F}_{5}\right)_{2}(\mathrm{DPA})\right] \mathrm{ClO}_{4}$ with the di-(2-picolyl)amine (DPA) ligand has been synthesised. In the solid state the complex has a chiral amine nitrogen because the ligand coordinates to the gold centre through one nitrogen atom from a pyridine and through the $\mathrm{NH}$ moiety, whereas in solution shows a fluxional behaviour with a rapid exchange between the pyridine sites. This complex can be used as excellent symptom to prepare new gold(III) carbene complexes by the reaction with isocyanide CNR. The resulting gold(III) derivatives have unprecedented bidentate $C^{\wedge} N$ acyclic carbene ligands. All the complexes have been spectroscopically and structurally characterized. Taking advantage of the fluxional behaviour of the amine complex, its catalytic properties have been tested in several reactions with formation of $\mathrm{C}-\mathrm{C}$ and $\mathrm{C}-\mathrm{N}$ bonds. The complex showed excellent activity with total conversion, without the presence of a co-catalyst, and with a catalyst loading as low as $0.1 \%$. These complexes also present biological properties and cytotoxicity studies have been performed in vitro against three tumour human cell lines, Jurkat (T-cell leukaemia), MiaPacaz (pancreatic carcinoma) and A549 (lung carcinoma). Some of them showed excellent cytotoxic activity compared with the reference cisplatin.
\end{abstract}

\section{Introduction}

Gold(III) derivatives are attracting much interest mainly because of their potential applications in diverse fields such as medicine as antitumor or antiviral agents, ${ }^{1-7}$ in material chemistry for their optical properties, with products with interesting luminescence ${ }^{8-10}$ or in catalysis, where the gold(III) complexes are active in several organic transformations, some of them of industrial interest. ${ }^{11-15}$

The discovery of the extraordinary properties of gold(I), and to a lesser extend gold(III), N-heterocyclic carbene compounds, especially in catalysis, ${ }^{16,17}$ medicine $^{18}$ and luminescence ${ }^{19}$ prompts the research in gold acyclic carbene derivatives. Nowadays, several gold(I) acyclic carbene complexes with outstanding catalytically activity have been reported, ${ }^{20-25}$ some of them with a very low catalyst loading and excellent turnover numbers, ${ }^{26}$ or with interesting luminescence properties. ${ }^{27-30}$ However, gold(III) acyclic carbene derivatives are very scarce and only a few have been described thus far, including the pioneering work of Bonati et $a l^{31,32}$ and those reported in our group. ${ }^{33-36}$ However, we believe that these gold(III) acyclic carbenes may exhibit a wide range of unexplored possibilities for this type of applications.

With this idea in mind, we proposed the preparation of new and novel gold(III) acyclic carbene complexes. Usually, metal acyclic carbenes are obtained by nucleophilic attack of an amine to a metal isocyanide complex. This procedure does not work easily for all the amines, and in some cases with aryl or less activated amines the reaction does not occur. We considered the possibility of using functionalised amine derivatives that upon coordination to the gold(III) centre could favour the reaction with isocyanide and formation of the carbene. $^{36}$ Consequently, the use of a wide range of funcionalised amines could open the entry to a great variety of unprecedented bidentate carbene ligands. Furthermore, these gold(III) synthons in which hemilabile bidentate amine ligands are coordinated to the metallic centre could be excellent catalysts in many organic processes. Not many gold(III) complexes have been successfully used in catalysis, apart from the widely used $\mathrm{AuCl}_{3}, \mathrm{AuBr}_{3}$ or $\mathrm{Na}\left[\mathrm{AuCl}_{4}\right]$ salts. ${ }^{37,38} \mathrm{Hashmi}$ 
et al reported the use of pyridine-based ligands for stabilising the gold(III) ion, ${ }^{39}$ a few examples of chiral gold(III) Schiff base complexes were reported by Corma et $a l,{ }^{40}$ and also some NHC, ${ }^{41-45}$ cyclometallated, ${ }^{46-48}$ salen, ${ }^{49}$ pentafluorophenyl ${ }^{50}$ or iminophosphorane derivatives ${ }^{51}$ have been used as catalysts. In most of the cases the complex is a pre-catalyst and activation with silver salts or acids is necessary.

Herein we report the design and synthesis of stable unprecedented gold(III) species with bidentate acyclic carbene ligands. For this purpose we have developed a pioneering procedure consisting in the preparation of gold(III) derivatives with functionalised amines. The latter compounds could be excellent synthons for the preparation of novel gold(III) species with bidentate acyclic carbenes through activation of isocyanides. Furthermore, this well-defined gold(III) compounds with hemilabile amines could be unique catalytic systems in several organic transformations, including multicomponent reactions for the synthesis of biological active species. Additionally, the antitumor properties of these complexes have been tested in vitro against three tumour human cell lines, such as Jurkat (T-cell leukaemia), MiaPaca2 (pancreatic carcinoma) and A549 (lung carcinoma).

\section{Results and discussion}

\section{Synthesis and characterisation}

The utilisation of the gold(III) precursor cis$\left[\mathrm{Au}\left(\mathrm{C}_{6} \mathrm{~F}_{5}\right)_{2}\left(\mathrm{OEt}_{2}\right)_{2}\right] \mathrm{ClO}_{4}$, which has two labile diethyl ether molecules, allows coordination of practically any ligand, and thus we have chosen functionalised amine di-(2-picolyl)amine to prepare the starting compound. Then, complex $\mathbf{1}$ has been obtained by the reaction at room temperature of cis$\left[\mathrm{Au}\left(\mathrm{C}_{6} \mathrm{~F}_{5}\right)_{2}\left(\mathrm{OEt}_{2}\right)_{2}\right] \mathrm{ClO}_{4}$, prepared in situ, with an equimolecular amount of di-(2-picolyl)amine (Scheme 1). It has been characterised by means of IR, elemental analysis, NMR spectroscopy, and mass spectrometry. Assignments of the ${ }^{1} \mathrm{H}$ NMR and ${ }^{13} \mathrm{C}$ NMR signals were made on the basis of $2 \mathrm{D}$ COSY and HSQC spectra. In the $\mathrm{ESI}^{+}$mass spectra the fragment $\left[\mathrm{M}-\mathrm{ClO}_{4}\right]^{+}$appears at $\mathrm{m} / \mathrm{z}=730(100 \%)$.

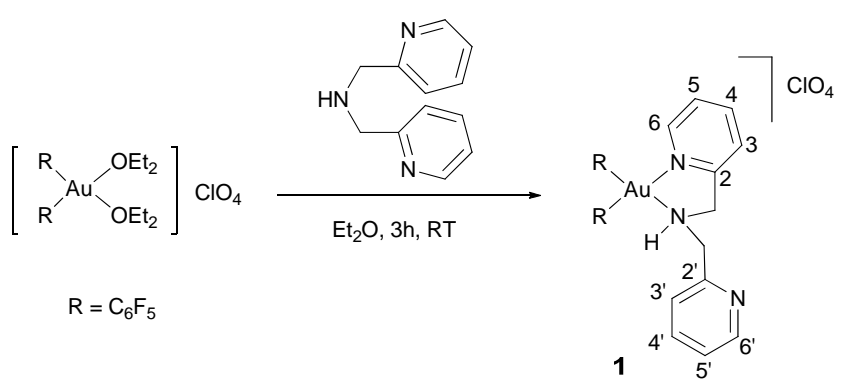

Scheme 1 Synthesis of complex 1.

The ${ }^{1} \mathrm{H}$ NMR spectrum of complex 1 (Fig. 1 A) shows resonances assigned to the protons of the di-(2-picolyl)amine (protons named $\mathrm{H}$ and $\mathrm{H}^{\prime}$ in Scheme 1). Since only one type of pyridine and methyl signals are observed at room temperature, at least two structures are possible in solution. One with both pyridine nitrogen atoms coordinated to the gold(III) (Scheme 2, a), other with the amine nitrogen bonded to the gold(III) and the pyridine nitrogen atoms in a dynamic exchange process that make them equivalent (Scheme 2, b).

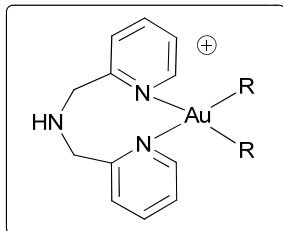

(a)

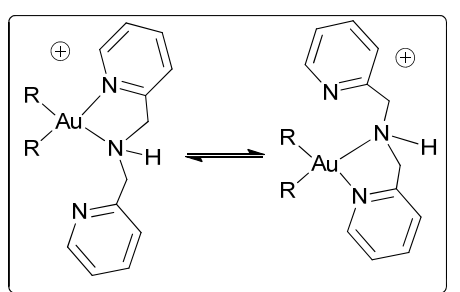

(b)
Scheme 2 a) non-fluxional behaviour, b) fluxional behaviour in solution

In order to obtain more information, the ${ }^{1} \mathrm{H}$ variable temperature spectra of $\mathbf{1}$ in $\left(\mathrm{CD}_{3}\right)_{2} \mathrm{CO}$ were carried out. As shown in Fig. 1, the signals began to broaden near $-35^{\circ} \mathrm{C}$, reached decoalescence point near $-55{ }^{\circ} \mathrm{C}$ and at $-73{ }^{\circ} \mathrm{C}$ each pyridine peaks was split into two broad peaks with a 1:1 ratio. The diastereotopic methylene protons $\mathrm{CH}_{\mathrm{a}} \mathrm{H}_{\mathrm{b}}$ were observed as two "AB" multiplets. At $200 \mathrm{~K}$ the structure with two different $-\mathrm{CH}_{2}$ py groups was confirmed (Fig. 1, D). This dynamic behaviour has also been observed in other gold(III) derivatives. ${ }^{52,53}$
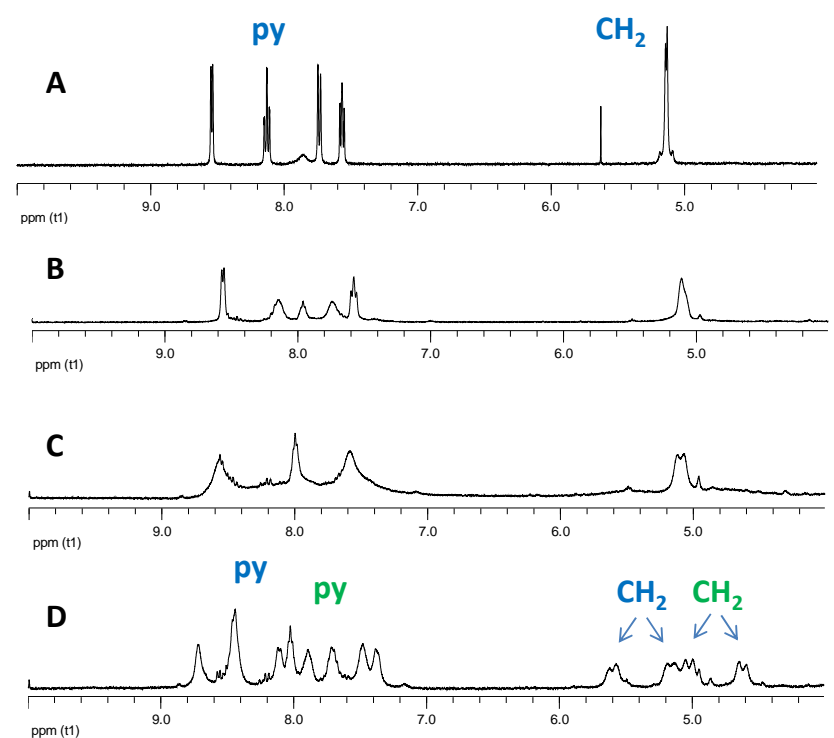

Figure $1^{1} \mathrm{H}$ NMR $\left(\mathrm{CD}_{3}\right)_{2} \mathrm{CO}$ spectra of complex 1. A: $298 \mathrm{~K}$. B: $238 \mathrm{~K}$. C: $218 \mathrm{~K}$. D: $200 \mathrm{~K}$.

The ${ }^{19} \mathrm{~F}$ NMR spectrum at room temperature presents two multiplets for the ortho and meta and a triplet for the para fluorine indicating that pentafluorophenyl groups become 
equivalents in solution and there is no hindered rotation for them. Variable temperature ${ }^{19} \mathrm{~F}$ NMR spectra have been measured (Fig. 2), showing that the signals decoalesced near $15{ }^{\circ} \mathrm{C}$. At $-73{ }^{\circ} \mathrm{C}$ appeared four multiplets for the ortho and meta fluorines, which are partially overlapped, and two pseudotriplets for the para fluorines. This spectrum corresponds to two different pentafluorophenyl groups that do not rotate at this temperature.

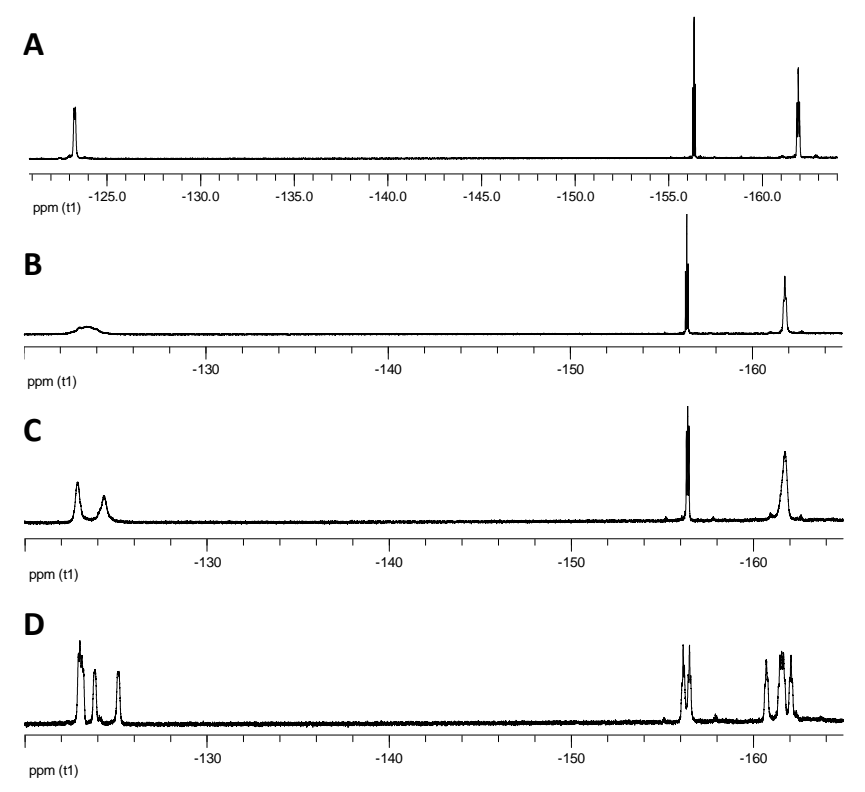

Figure $2{ }^{19} \mathrm{~F} \mathrm{NMR}\left(\mathrm{CD}_{3}\right)_{2} \mathrm{CO}$ spectra of complex 1. A: $298 \mathrm{~K}, \mathrm{~B}: 258 \mathrm{~K}, \mathrm{C}: 238 \mathrm{~K}, \mathrm{D}$ : $200 \mathrm{~K}$.

The structure of complex $\mathbf{1}$ in solid state was solved by Xray diffraction spectroscopy showing that the amine nitrogen atom and one pyridine nitrogen atom are coordinated to the gold(III) centre, in a slightly distorted square-planar geometry (Fig. 3). Complex 1 crystallizes in the monoclinic P2(1)/c space group. Mean deviation from the plane formed by the four donor atoms of the gold centre is $0.0381 \AA(\mathrm{N} 1, \mathrm{~N} 2, \mathrm{C} 1, \mathrm{C} 11)$. The distance between the other pyridine nitrogen and the gold atom is $2.888 \AA$, too long to be considered a bond but enough short to explain the fluxional behaviour observed in solution. This distance, shorter than the sum of the van der Waals radii of gold and nitrogen atoms (3.21 $\AA$ ), suggests some secondary bonding interaction. As can be seen in Fig. 3, the nitrogen atom of the non-coordinated pyridine (N3) seems to be located in direction of the gold atom, ready for bonding. This might explain the fluxional behaviour observed in solution. Considering the second nitrogen atom a pseudo-fivecoordinated geometry is observed around the gold centre. Although not many examples of pseudo-five-coordinate gold(III) complexes are known, ${ }^{54}$ some of them have been recently published. ${ }^{55,56}$ An interesting feature of solid complex $\mathbf{1}$ is that the amine nitrogen of picolylamine group becomes chiral after its coordination to the gold(III) atom.

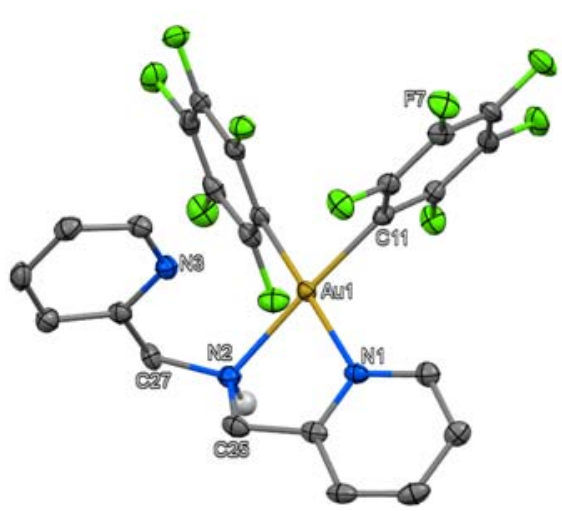

Figure 3 Diagram of the cation of complex 1 with 50\% probability ellipsoids. Hydrogen atoms (except $\mathrm{NH}$ ) are omitted for clarity. Selected bond lengths $[\AA ̊]$ and angles [deg] for complex 1: $\mathrm{Au}(1)-\mathrm{C}(11)$ 2.006(4); $\mathrm{Au}(1)-\mathrm{C}(1) \quad 2.018(4)$; $\mathrm{Au}(1)-\mathrm{N}(1)$ 2.073(4); $\mathrm{Au}(1)-\mathrm{N}(2)$ 2.115(4); C(11)-Au(1)-C(1) 86.47(1); C(11)-Au(1)$\mathrm{N}(1)$ 95.53(15); C(1)-Au(1)-N(2) 97.94(15); N(1)-Au(1)-N(2) 80.11(14).

The reaction of $\left[\mathrm{Au}\left(\mathrm{C}_{6} \mathrm{~F}_{5}\right)_{2}(\mathrm{DPA})\right] \mathrm{ClO}_{4}$ (1) with an equimolecular amount of the corresponding isocyanide CNR (R = 2-naphthyl, cyclohexyl, 2,6-dimethylphenyl) gives complexes $\mathbf{2 - 4}$, respectively, in which the nucleophilic attack of the amine coordinated to the gold(III) centre to the isocyanide produces the formation of unprecedented bidentate $\mathrm{N}^{\wedge} \mathrm{C}$ acyclic carbenes (Scheme 3). They have been characterized by means of IR, elemental analysis, NMR spectroscopy, and mass spectrometry. Assignments of the ${ }^{1} \mathrm{H}$ NMR and ${ }^{13} \mathrm{C}$ NMR signals were made on the basis of ${ }^{2} \mathrm{D}$ COSY and HSQC spectra. The ${ }^{1} \mathrm{H}$ NMR spectra of complexes show the resonances assigned to the protons of the di-(2-picolyl)amine ligands (protons named $\mathrm{H}$ and $\mathrm{H}^{\prime}$ in Scheme 3 ) and the signals characteristic of the isocyanide group ( $\left.\mathrm{H}^{\prime \prime}\right)$. Two different diastereotopic methylene protons were observed as two "AB" quartets (in 2 and 3) or multiplets (in 4). In these spectra is possible to observe that the complexes do not show any fluxional behaviour in solution, probably because the coordination of the $\mathrm{N}$-acyclic ligand with a delocalised NCN unit makes the rotation more hindered. The ${ }^{19} \mathrm{~F}$ NMR spectra of $\mathbf{2}, \mathbf{3}$ and $\mathbf{4}$ show two different para fluorines accordingly with two different $\mathrm{C}_{6} \mathrm{~F}_{5}$ groups, and for each one two different ortho and meta fluorines (in a 1:1 ratio). This indicates that the pentafluorophenyl rings cannot rotate at room temperature. In the $\mathrm{ESI}^{+}$mass spectra the fragments $[\mathrm{M}-$ $\left.\mathrm{ClO}_{4}\right]^{+}$of 2, 3 and 4 appear at $\mathrm{m} / \mathrm{z}(\%)=883(100), 839$ (100), 861 (100), respectively. 
<smiles>[R][Y]([R])([H])N1Cc2ccccc2N1Cc1ccccn1</smiles><smiles></smiles>

DCM/Acet $\mathrm{R}=\mathrm{C}_{6} \mathrm{~F}_{5}$

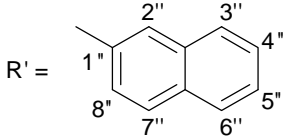<smiles>CC1CCCCC1</smiles>

3
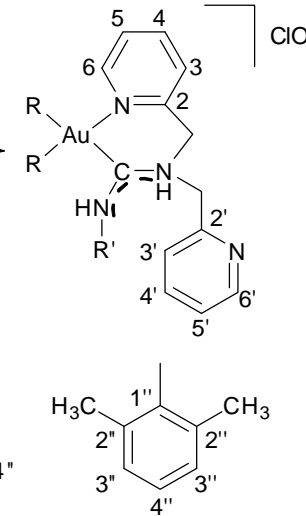

4
Scheme 3 Synthesis of complexes 2-4

The crystal structures of complexes 2,3 and $\mathbf{4}$ have been determined by X-ray diffraction studies. All of them crystallised in the triclinic space group P-1 with one molecule in the asymmetric unit (Fig. 4, 5 and 6). The gold atoms in these complexes show a distorted square-planar $\mathrm{AuC}_{\text {carbene }} \mathrm{N}_{\mathrm{py}} \mathrm{C}_{2 \text { pentafluorophenyl }}$ coordination. Mean deviations from the planes formed by the four donor atoms of the gold centres are $0.0525 \AA(\mathrm{C} 37, \mathrm{~N} 1, \mathrm{C} 1, \mathrm{C} 11)(2), 0.0512 \AA(\mathrm{C} 37$, $\mathrm{N} 3, \mathrm{C} 1, \mathrm{C} 11)(3)$, and $0.0684 \AA(\mathrm{C} 49, \mathrm{~N} 1, \mathrm{C} 1, \mathrm{C} 11)(4)$.

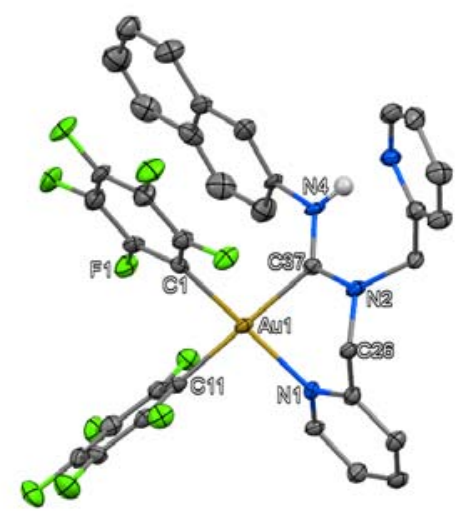

Figure 4 Diagram of the cation of $\mathbf{2}$ with $50 \%$ probability ellipsoids. Hydrogen atoms (except $\mathrm{NH}$ ) are omitted for clarity. Selected bond lengths $[\mathrm{A}]$ and angles [deg] for complex 2: $A u(1)-C(1)$ 2.030(7); $A u(1)-C(11)$ 2.059(8); $A u(1)-C(37)$ 2.066(7); $\mathrm{Au}(1)-\mathrm{N}(1)$ 2.094(6); N(2)-C(37) 1.324(9); $\mathrm{C}(37)-\mathrm{N}(4) \quad 1.332(9) ; \mathrm{C}(1)$ $\mathrm{Au}(1)-\mathrm{C}(11)$ 88.9(3); C(1)-Au(1)-C(37) 91.5(3); C(11)-Au(1)-N(1) 92.5(3); C(37)$\mathrm{Au}(1)-\mathrm{N}(1) \quad 87.1(3) ; \mathrm{N}(2)-\mathrm{C}(37)-\mathrm{N}(4)$ 119.5(7); N(2)-C(37)-Au(1) 116.3(5); N(4)$\mathrm{C}(37)-\mathrm{Au}(1)$ 124.1(5)

The angles around the gold(III) atoms range from $84.99(10)^{\circ}$ to 94.91(10 $)^{\mathrm{o}}$. The smallest one in each compound corresponds to the $\mathrm{C}_{\text {carbene }}-\mathrm{Au}-\mathrm{N}_{\mathrm{py}}$ angle. The $\mathrm{Au}(\mathrm{III})-\mathrm{C}_{\text {pentaflourophenyl }}$ bond distances range from 2.012(3) to 2.067(3) $\AA$ and the Au-N bond distances from 2.091(2) to 2.094(3) $\AA$. In each complex, the longest $\mathrm{Au}-\mathrm{C}_{\text {pentafluorophenyl bond length corresponds to the }}$ distance trans to the $\mathrm{Au}(\mathrm{III})-\mathrm{C}_{\text {carbene }}$ bond, in agreement with the high trans influence of the carbene group compared with $\mathrm{N}$ ligands. The other Au- $\mathrm{C}_{\text {pentafluoropheny }} 1$ is similar to that found in complex 1 and in other complexes with pentafluorophenyl rings trans to $\mathrm{N}$-ligands. ${ }^{57}$

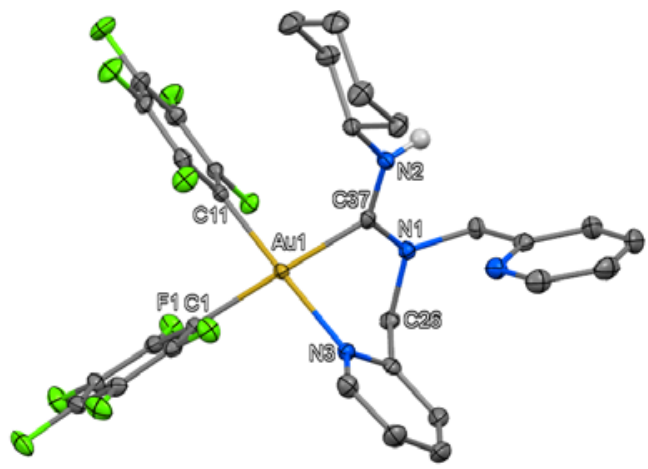

Figure 5 Diagram of the cation of 3 with $50 \%$ probability ellipsoids. Hydrogen atoms (except $\mathrm{NH}$ ) are omitted for clarity. Selected bond lengths $[\mathrm{A}]$ and angles [deg] for complex 3: $A u(1)-C(11)$ 2.017(3); $A u(1)-C(1)$ 2.067(3); $A u(1)-C(37)$ 2.084(3); $\mathrm{Au}(1)-\mathrm{N}(3) \quad 2.091(2) ; \mathrm{N}(1)-\mathrm{C}(37)$ 1.339(3); N(2)-C(37) 1.323(3); C(11)$\mathrm{Au}(1)-\mathrm{C}(1)$ 86.85(10); C(11)-Au(1)-C(37) 93.06(10); C(1)-Au(1)-N(3) 94.91(10); $\mathrm{C}(37)-\mathrm{Au}(1)-\mathrm{N}(3) \quad 84.99(10) ; \quad \mathrm{N}(2)-\mathrm{C}(37)-\mathrm{N}(1) \quad 120.5(2) ; \quad \mathrm{N}(2)-\mathrm{C}(37)-\mathrm{Au}(1)$ 124.59(19); N(1)-C(37)-Au(1) 114.89(18).

The six-membered $\mathrm{AuC}_{3} \mathrm{~N}_{2}$ chelate ring adopts in all of them a boat conformation as can be seen in Fig. 6 for the complex 4, with the $\mathrm{Au}$ atom and the methylene carbon lying to the same side of the plane of the other four atoms, $\mathrm{C}_{2} \mathrm{~N}_{2}$, which are almost coplanar.

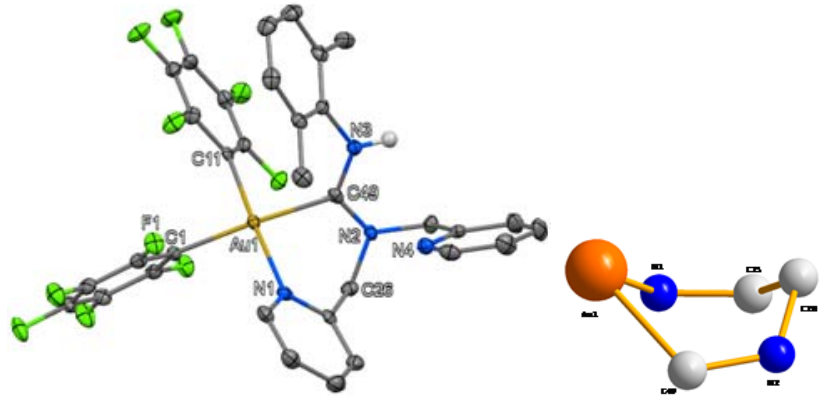

Figure 6 Diagram of the cation of complex 4 with 50\% probability ellipsoids. Hydrogen atoms (except $\mathrm{NH}$ ) are omitted for clarity. Selected bond lengths $[\mathrm{A}]$ and angles [deg] for complex 4: $\mathrm{Au}(1)-\mathrm{C}(11)$ 2.012(3); $\mathrm{Au}(1)-\mathrm{C}(1)$ 2.066(4); $\mathrm{Au}(1)$ $\mathrm{C}(49)$ 2.070(3); $\mathrm{Au}(1)-\mathrm{N}(1)$ 2.094(3); $\mathrm{N}(2)-\mathrm{C}(49)$ 1.333(4); $\mathrm{N}(3)-\mathrm{C}(49)$ 1.323(4); $\mathrm{C}(11)-\mathrm{Au}(1)-\mathrm{C}(1) \quad 88.64(13) ; \quad \mathrm{C}(11)-\mathrm{Au}(1)-\mathrm{C}(49) \quad 92.13(13) ; \quad \mathrm{C}(1)-\mathrm{Au}(1)-\mathrm{N}(1)$ 93.59(12); C(49)-Au(1)-N(1) 85.27(12); N(3)-C(49)-N(2) 120.5(3); N(3)-C(49)$\mathrm{Au}(1) 125.5(3) ; \mathrm{N}(2)-\mathrm{C}(49)-\mathrm{Au}(1) \mathrm{114.4(2).} \mathrm{Boat} \mathrm{conformation} \mathrm{of} \mathrm{the} \mathrm{metallacycle}$ in complex 4.

\section{Cytotoxic activity}

In the last years a number of gold(III) compounds that are highly cytotoxic towards cancer cells have been discovered. ${ }^{1-7}$ Among the families of gold(III) complexes that are stable under physiological-like conditions and have significant antiproliferative properties in vitro, are gold dithiocarbamates, ${ }^{6}$ gold porphyrins, ${ }^{4,58}$ gold bypridines ${ }^{59}$ and a variety of organogold compounds mainly derived from cyclometallated 
derivatives. $^{60,61}$ These compounds are not only strongly cytotoxic, but they are also able to overcome cisplatin resistance and they exert their antiproliferative activity through a broader scope of targets than the latter. Studies suggested that heterogeneous molecular mechanisms are involved including inhibition of cyclin-dependent kinases or histone deacetylases. ${ }^{62}$

Since our complexes are organogold amine-pyridine species or with bidentate chelate $\mathrm{C}^{\wedge} \mathrm{N}$ ligands, which can be considered analogous to cyclometallated ligands, we envisaged the great potential of these compounds for having antiproliferative activity. Consequently, the cytotoxic activity of complexes 1-4 was tested against three different human tumour cell lines: Jurkat (T-cell leukaemia), MiaPaca2 (pancreatic carcinoma) and A549 (lung carcinoma), compared to the results with cisplatin.

Compounds 1-4 are not soluble in water, but they are soluble in DMSO and in the DMSO/water mixtures used in the tests, which contain a small amount of DMSO. We did not observe any precipitation of the complexes or metallic gold while performing the tests. Moreover, no protonation of the pyridine unit is produced in these conditions, and only with addition of an excess of acetic acid, protonation takes place. Their colourless $\mathrm{D}_{6}$-DMSO solutions are very stable at room temperature, as shown in the ${ }^{1} \mathrm{H}$ NMR spectra in which the signals remain the same for weeks. Cells were exposed to different concentrations of each compound for a total of $24 \mathrm{~h}$. Using the colorimetric MTT viability assay, ${ }^{63}$ (MTT $=3-(4,5-$ dimethyl-thiazol-2-yl)-2,5-diphenyltetrazolium bromide), the $\mathrm{IC}_{50}$ values (final concentration $<0.5 \%$ DMSO) were calculated from dose-response curves obtained by nonlinear regression analysis. $\mathrm{IC}_{50}$ values are concentrations of a drug required to inhibit tumour cell proliferation by $50 \%$, compared to the control cells treated with DMSO alone. The $\mathrm{IC}_{50}$ values for complexes 1-4 are collected in Table 1. Cytotoxicity values of cisplatin (chemotherapeutic platinum clinically employed) are tested too and used for comparison purposes.

Table 1. $\mathrm{IC}_{50}(\mu \mathrm{M})(24 \mathrm{~h})$ of complexes against Jurkat, MiaPaca2 and A549.

\begin{tabular}{cccc}
\hline & & & \\
\hline Compounds & Jurkat & MiaPaca2 & A549 \\
\hline Cisplatin $^{\mathrm{a}}$ & $10.8 \pm 1.2$ & $114.2 \pm 9.1$ & $76.5 \pm 7.4$ \\
(1) & $9.09 \pm 1.2$ & $>25$ & $>25$ \\
(2) & $0.79 \pm 0.7$ & $1.74 \pm 0.8$ & $17.51 \pm 1.7$ \\
(3) & $4.55 \pm 0.9$ & $9.11 \pm 1.0$ & $20.45 \pm 1.8$ \\
(4) & $1.26 \pm 0.6$ & 25 & $1.52 \pm 0.8$ \\
\hline
\end{tabular}

${ }^{\text {a }}$ cisplatin was dissolved in $\mathrm{H}_{2} \mathrm{O}$

As can be observed, all the complexes synthesised were active against all the different tumour cell lines in low concentrations (low micromolar range). The Jurkat cell line was the most sensitive to our compounds, while A549 or MiaPaca2 showed more resistance to the complexes. The starting amine complex $\mathbf{1}$ is the less active of these complexes. However, the compounds with the $\mathrm{N}$-acyclic carbenes exhibit good antiproliferative activities, with $\mathrm{IC}_{50}$ values ranging from 1.52 to $20.45 \mu \mathrm{M}$ in A549 cells, 0.79 to $4.55 \mu \mathrm{M}$ in Jurkat cells, and 1.74 to $25 \mu \mathrm{M}$ in MiaPaca2. These values are very low if we take into account that they are measured at $24 \mathrm{~h}$ and that very tough cell lines (MiaPaca2 and A549) have been used. It is remarkable that these values are much lower than the corresponding to cisplatin.

There is not much data of the activity of gold(III) species in these cell lines, but the examples reported by Messori et al for cyclometallated compounds in A549 cell lines gave values around $50 \mu \mathrm{M}$ after $72 \mathrm{~h}$ exposure to the drugs, or bypirine gold(III) derivatives studied also in A549 were negligible. These results show that our complexes present an outstanding activity in all the cell lines, but it is noteworthy that the values of $1.74 \mu \mathrm{M}$ for complex 2 in MiaPaca2 and $1.52 \mu \mathrm{M}$ for complex 4 in A549 are very promising in order to continue the evaluation and mechanism studies of these metallo-drugs.

Several NMR experiments have been carried out in order to understand how these complexes could behave in biological media, and exert their cytotoxic activity. Addition of biological molecules such as L-cysteine or BSA (bovine serum albumin) to complex 3 in a DMSO- $d 6 / \mathrm{D}_{2} \mathrm{O}$ mixture shows that interaction of these molecules with the gold(III) $\mathrm{N}$-acyclic carbenes occurs, probably by displacement of the pyridine moiety by the sulfur atom of the cysteine fragment. This could indicate that the activity of these complexes could involve the interaction with relevant enzimes containing cysteine moieties.

\section{Catalytic activity of complex 1}

In this broad spectrum of properties and taking into account the fluxional behaviour in solution observed for complex $\mathbf{1}$, we envisioned the possibility of testing this structure as a promising candidate for homogeneous catalysis. In this respect, at least one of the four positions around gold atom would be almost free and suitable to coordinate the substrates. It is remarkable that the addition of an external co-catalyst such as a Ag salt is not necessary in this case. Over the last decade, gold catalysis has undergone an impressive development and proof of that is the increasing number of publications reported in this area of reseach. ${ }^{64-70}$ Among the number of gold catalysed reactions we decided to explore three different benchmark reactions (Fig. 7). 


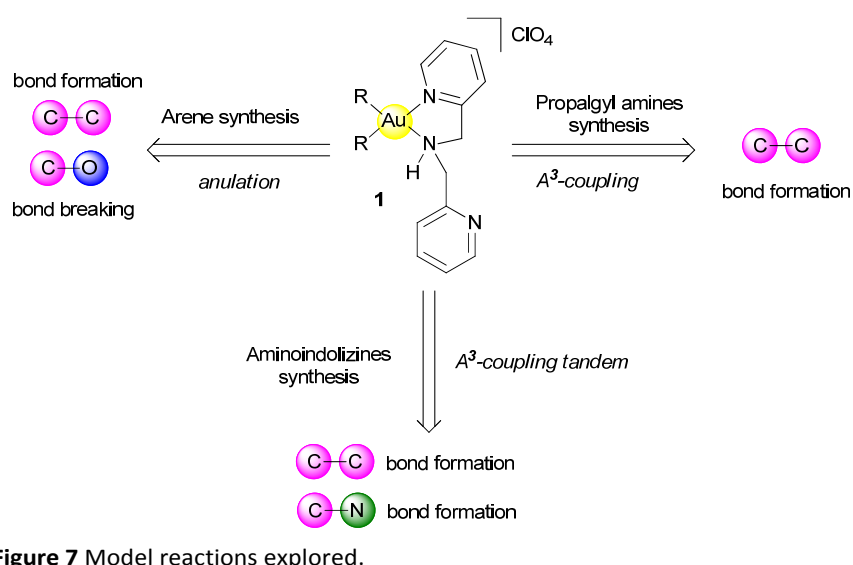

Figure 7 Model reactions explored.

In order to explore the efficiency of our active candidate $\mathbf{1}$, we firstly tested its activity in the appealing reaction for the phenol synthesis from furan derivative $\mathbf{5}$ showed in Scheme 4 . Catalytic activity of $\mathrm{AuCl}_{3}$ to produce a highly substituted phenol 6 without side products was first reported by Hashmi et al. ${ }^{71-74}$ Our reaction was easily monitored by ${ }^{1} \mathrm{H}$ NMR spectroscopy in $\left(\mathrm{CD}_{3}\right)_{2} \mathrm{CO}$ and in $\mathrm{CDCl}_{3}$ without special conditions, being our catalyst tolerant to different reaction media. Interestingly, no reduction to metallic gold was observed during reaction and an almost complete conversion in 6 without side-products has been observed after 24 or $72 \mathrm{~h}$ at room temperature.

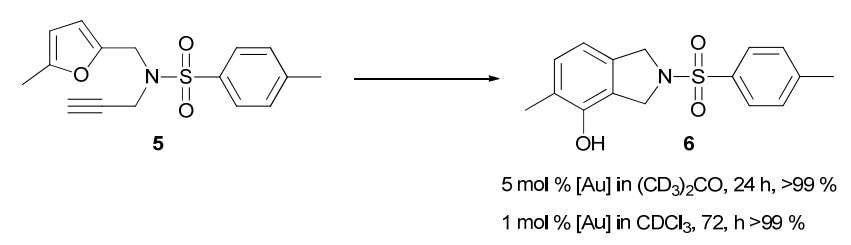

Scheme 4 Synthesis of a phenol 6 from furan derivative 5

Encouraged by this interesting result we examined another appealing target reaction, such the formation of propargylamines via $\mathrm{A}^{3}$-coupling reaction, ${ }^{75}$ in order to extend our catalytic study. The core of these structures is present in many nitrogen-containing natural products and drug molecules and their synthesis are very interesting since they are versatile synthetic intermediates. However, to the best of our knowledge the use of catalytic amounts of gold-based catalysts in this $\mathrm{A}^{3}$ coupling procedure has been shortly developed. ${ }^{49,76}$ In addition, multicomponent processes are of great interest from atom economy point of view allowing the generations of compound libraries and their development have been focused of an increasing interest over the years. ${ }^{77}$ For few representative examples of this reaction we have synthesised the structures 1214 illustrated in Scheme 5 using different amines 8-10.

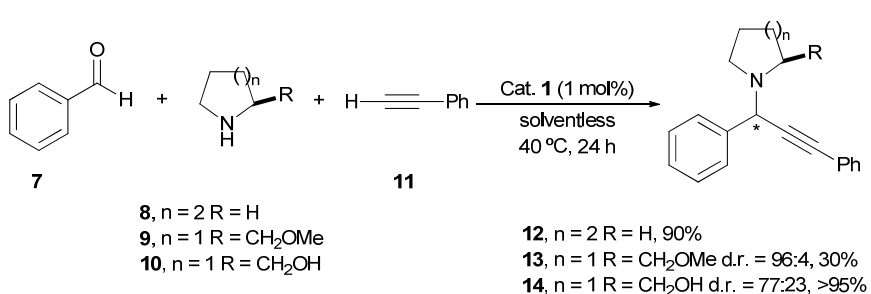

Scheme 5 Synthesis of propargylamines via three-component coupling reaction.

Interestingly, we were able to perform these reactions with only $1 \mathrm{~mol} \%$ of catalyst $\mathbf{1}$ and it is also noteworthy that the methodology was carried out in absence of solvent, an interesting aspect from a sustainable point of view, without inert atmosphere and in the presence of light, in contrast to previous protocols. ${ }^{49}$ The reactions were controlled by ${ }^{1} \mathrm{H}$ NMR $\left(\mathrm{CDCl}_{3}\right)$ and the crudes remained very clean without sideproducts after 24 hours. The observed diastereoselection in $\mathbf{1 3}$ and $\mathbf{1 4}$ reveals that the chirality in the new formed $\mathrm{sp}^{3}$ carbon centre depends on the $\alpha$-substituents on the prolinol derivatives. This process is a proof of fact of the versatility of our catalytic complex.

We also intended to explore the possibility of synthesizing indolizines in a tandem reaction involving a multicomponent approach (Scheme 6), in order to expand the spectrum of reactivity and the potential of $\mathbf{1} .^{78}$ Indolizines are a privileged structural motif found in a variety of potent biological active compounds and in a variety of applications for drug discovery. ${ }^{79}$ Gold-based catalysts have been rare involved in the synthesis of indolizines, ${ }^{80-83}$ and there is only one example where the authors perform the synthesis following a tandem multicomponent strategy. ${ }^{82}$ Due to the short background of this reaction in gold catalysts together with the interesting biological properties of indolizines, the development of new efficient, general and eco-friendly protocols using benign catalysts still remains a continuous demand. For such propose we set out the exploration of the catalytic activity of our complex 1 in the model reaction depicted in Scheme 6.

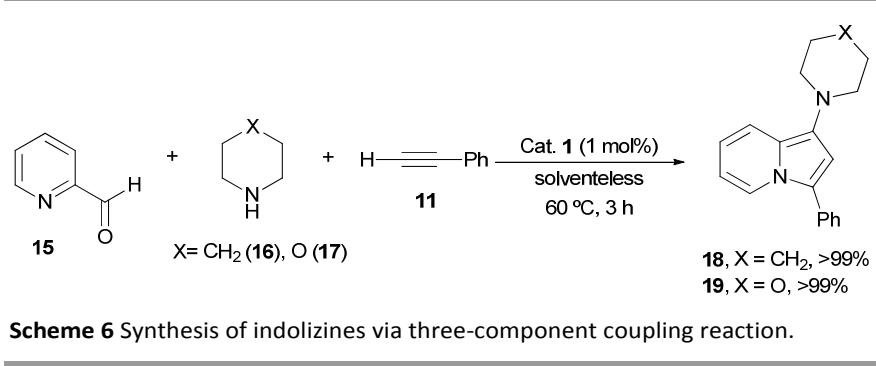

The reactions were conducted by heating 1 ( $0.05 \mathrm{mmol})$, 2pyridinaldehyde $(0.50 \mathrm{mmol})$, amine 16 or $17(0.55 \mathrm{mmol})$, and phenylacetylene $11(0.6 \mathrm{mmol})$ in absence of solvent, without inert atmosphere at $60{ }^{\circ} \mathrm{C}$ for $3 \mathrm{~h}$. We were pleased to find that the catalyst also promoted this process with excellent results 
( $>99)$. The final crudes were very clean and the final products are almost pure. With these results in hand and with the continuous concern about sustainable chemistry we focused our efforts in decreasing the amount of catalyst without impairing the yield of the process (Scheme 7), since efforts are pushed in decreasing the amount of gold catalysts.

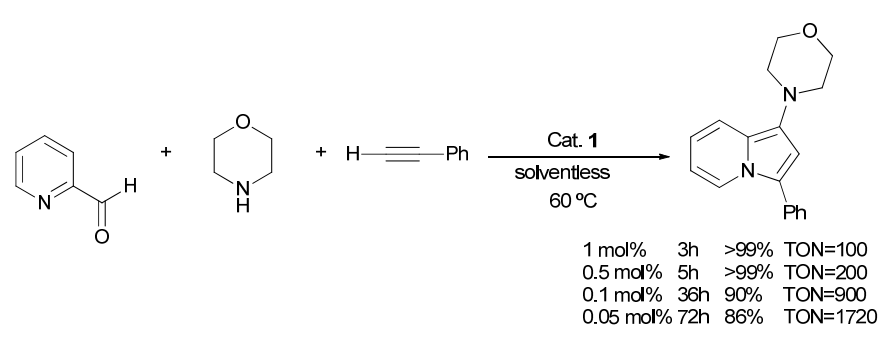

Scheme 7 Study of the efficiency of catalyst 1.

Complex $\mathbf{1}$ is the best candidate as catalyst for its hemilability, since this is not observed in solution for the $\mathrm{N}$-acyclic carbene complexes 2-4. However, they could also act as catalysts if displacement of the pyridine group takes place. In normal conditions, at r.t., reaction with nucleophiles such as $\mathrm{PPh}_{3}$ or $\mathrm{PhC} \equiv \mathrm{CH}$ does not occur, but complex $\mathbf{3}$ shows catalytic activity in the synthesis of indolizines at $60{ }^{\circ} \mathrm{C}$, although with lower yield compared to complex 1.

In spite of the great progress achieved in homogeneous gold catalysis, in many cases the catalytic charge of gold is higher than $1 \mathrm{~mol} \%$ and normally the use of an additional $\mathrm{Ag}$ salt is necessary. This necessity opens the possibility of developing new more active structures. In our case, we explored the reactivity with different catalytic charges and excellent results were reached even at $0.1 \mathrm{~mol} \%$ and at $0.05 \mathrm{~mol} \%$ although with longer reaction times. This also demonstrates the stability of our catalyst since we do not appreciate decomposition in the reaction crude and we are convinced that the reaction could finish with longer reaction times.

\section{Experimental}

\section{General Measurements and Analysis Instrumentation}

$\mathrm{C}, \mathrm{H}$, and $\mathrm{N}$ analysis were carried out with a PERKIN-ELMER 2400 microanalyzer. Mass spectra were recorded on a VG Autospec, with the ESI technique. ${ }^{1} \mathrm{H},{ }^{13} \mathrm{C}\{\mathrm{H}\}$ and ${ }^{19} \mathrm{~F}$ NMR, including ${ }^{2} \mathrm{D}$ experiments, were recorded at room temperature on a BRUKER AVANCE 400 spectrometer $\left({ }^{1} \mathrm{H}, 400 \mathrm{MHz},{ }^{13} \mathrm{C}\right.$, 100.6 MHz) or at low temperature on a BRUKER AVANCE II 300 spectrometer $\left({ }^{1} \mathrm{H}, 300 \mathrm{MHz},{ }^{13} \mathrm{C}, 75.5 \mathrm{MHz}\right)$, with chemical shifts $(\delta, \mathrm{ppm})$ reported relative to the solvent peaks of the deuterated solvents. ${ }^{84}$

\section{Materials and Procedures}

The starting material $\left[\mathrm{Au}\left(\mathrm{C}_{6} \mathrm{~F}_{5}\right)_{2}\left(\mathrm{OEt}_{2}\right)_{2}\right] \mathrm{ClO}_{4}$ was prepared by published procedure. ${ }^{85}$ All other reagents were commercially available. Solvents were used as received without purification or drying.

Caution: perchlorate salts with organic cations might be explosive.

Synthesis of the Complex 1. Di-(2-picolyl)amine (0.0598 g, $0.3 \mathrm{mmol}, \rho=1.107 \mathrm{~g} / \mathrm{mL}$ ) was added to a freshly prepared solution of $\left[\mathrm{Au}\left(\mathrm{C}_{6} \mathrm{~F}_{5}\right)_{2}\left(\mathrm{OEt}_{2}\right)_{2}\right] \mathrm{ClO}_{4}(0.2336 \mathrm{~g}, 0.3 \mathrm{mmol})$ in diethyl ether $(20 \mathrm{~mL})$, and the mixture was stirring for $3 \mathrm{~h}$. Complex 1 precipitated as beige solid and was filtered off. Yield: $0.2399 \mathrm{~g}(96 \%)$. Anal. Calcd for $\mathrm{C}_{24} \mathrm{H}_{13} \mathrm{AuClF}_{10} \mathrm{~N}_{3} \mathrm{O}_{4}$ (829.78): C 34.74, H 1.58, N 5.06. Found: C 34.56, H 1.93, N 4.86. IR: (NH): 3150; $\left(\mathrm{C}_{6} \mathrm{~F}_{5}\right): 1508,969 ;\left(\right.$ cis- $\left.\mathrm{C}_{6} \mathrm{~F}_{5}\right): 818,807$; $\left(\mathrm{ClO}_{4}\right): 1072,622 \mathrm{~cm}^{-1} .{ }^{1} \mathrm{H}$ NMR $\left(400 \mathrm{MHz},\left(\mathrm{CD}_{3}\right)_{2} \mathrm{CO}\right): \delta$ $8.53\left(\mathrm{~m}, 2 \mathrm{H}, 6-\mathrm{H}, 6{ }^{\prime}-\mathrm{H}\right), 8.13\left(\mathrm{td},{ }^{3} \mathrm{~J}_{\mathrm{HH}}=7.8 \mathrm{~Hz},{ }^{4} \mathrm{~J}_{\mathrm{HH}}=1.5 \mathrm{~Hz}\right.$, 2H, 4-H, 4'-H), 7.85 (m, 1H, NH), 7.74 (m, 2H, 3-H, 3'-H), $7.56\left(\mathrm{~m}, 2 \mathrm{H}, 5-\mathrm{H}, 5^{\prime}-\mathrm{H}\right), 5.16,5.10\left(2 \mathrm{~d}, \mathrm{AB}\right.$ system, $4 \mathrm{H},{ }^{2} \mathrm{~J}_{\mathrm{AB}}=$ $\left.17.2 \mathrm{~Hz}, \mathrm{CH}_{2}\right) \mathrm{ppm} .{ }^{1} \mathrm{H}$ NMR $\left(300 \mathrm{MHz},\left(\mathrm{CD}_{3}\right)_{2} \mathrm{CO}, 200 \mathrm{~K}\right) \delta$ : 8.57 (m, 2H, 6-H, 6'-H), 8.06 (m, 2H, 4-H, 4'-H), 7.78 (m, 2H, 3-H, 3'-H), 7.41 (m, 2H, 5-H, 5'-H), 5.59, 5.15 (2d, AB system, $\left.{ }^{2} \mathrm{~J}_{\mathrm{AB}}=14.5 \mathrm{~Hz}, 2 \mathrm{H}, \mathrm{CH}_{2}\right), 5.02,4.61\left(2 \mathrm{~d}, \mathrm{AB}\right.$ system, ${ }^{2} \mathrm{~J}_{\mathrm{AB}}=$ $\left.16.9 \mathrm{~Hz}, 2 \mathrm{H}, \mathrm{CH}_{2}\right) \mathrm{ppm} .{ }^{19} \mathrm{~F}$ NMR $\left(400 \mathrm{MHz},\left(\mathrm{CD}_{3}\right)_{2} \mathrm{CO}\right): \delta-$ $123.3\left(\mathrm{~d},{ }^{3} \mathrm{~J}_{\mathrm{o}-\mathrm{F}, \mathrm{m}-\mathrm{F}}=21.3 \mathrm{~Hz}, 4 \mathrm{~F}, \mathrm{o}-\mathrm{F}\right),-156.4\left(\mathrm{t},{ }^{3} \mathrm{~J}_{\mathrm{p}-\mathrm{F}, \mathrm{m}-\mathrm{F}}=19.4\right.$ $\mathrm{Hz}, 2 \mathrm{~F}, \mathrm{p}-\mathrm{F}),-162.0(\mathrm{~m}, 4 \mathrm{~F}, \mathrm{~m}-\mathrm{F}) \mathrm{ppm} .{ }^{19} \mathrm{~F}$ NMR $(300 \mathrm{MHz}$, $\left.\left(\mathrm{CD}_{3}\right)_{2} \mathrm{CO}, 200 \mathrm{~K}\right) \delta$ : $-123.1(\mathrm{~m}, 2 \mathrm{~F}, \mathrm{o}-\mathrm{F}) ;-123.9(\mathrm{~m}, 1 \mathrm{~F}, \mathrm{o}-\mathrm{F}),-$ $125.1\left(\mathrm{~m}, 1 \mathrm{~F}, \mathrm{o}-\mathrm{F}_{\text {orto }}\right),-156.2$ (" $\mathrm{t}$ ", $\left.{ }^{3} \mathrm{~J}_{\mathrm{p}-\mathrm{F}, \mathrm{m}-\mathrm{F}}=17.7 \mathrm{~Hz}, 1 \mathrm{~F}, \mathrm{p}-\mathrm{F}\right)$, 156.5 (“" t", $\left.{ }^{3} \mathrm{~J}_{\mathrm{p}-\mathrm{F}, \mathrm{m}-\mathrm{F}}=20.8 \mathrm{~Hz}, 1 \mathrm{~F}, \mathrm{p}-\mathrm{F}\right),-160.8$ (m, 1F, m-F), $161.6(\mathrm{~m}, 2 \mathrm{~F}, \mathrm{~m}-\mathrm{F}),-162.1$ (m, 1F, m-F) ppm. ${ }^{13} \mathrm{C}\left\{{ }^{1} \mathrm{H}\right\} \mathrm{NMR}$ (300 MHz, $\left.\left(\mathrm{CD}_{3}\right)_{2} \mathrm{CO}\right): \delta 158.4$ (s, 2C, 2-C, 2'-C), 148.4 (s, 2C, 6-C, 6'-C), 140.4 (s, 2C, 4-C, 4'-C), 124.8 (s, 2C, 5-C, 5'-C), 123.5 (s, 2C, 3-C, 3'-C), 58.5 (s, 2C, $\left.\mathrm{CH}_{2}\right)$ ppm. MS $\left(\mathrm{ESI}^{+}\right)$: $\mathrm{m} / \mathrm{z}(\%) 730(100)\left[\mathrm{M}-\mathrm{ClO}_{4}\right]^{+}$.

General Procedure of the Synthesis of the Complexes 2-4. A mixture of CN-naphthnaphthylyl $(0.0306 \mathrm{~g}, 0.2 \mathrm{mmol}), \mathrm{CN}-$ cyclohexyl $(0.0218 \mathrm{~g}, 0.2 \mathrm{mmol})$, or CN-xylyl (0.0262 g, 0.2 $\mathrm{mmol})$ and complex $1(0.1660 \mathrm{~g}, 0.2 \mathrm{mmol})$ in a mixture dichloromethane/acetone $(20 \mathrm{~mL} / 5 \mathrm{~mL})$, was stirred at room temperature. After stirring during $24 \mathrm{~h}$, the solution was filtered over Celite. The volume was reduced to $5 \mathrm{~mL}$, and addition of n-hexane for $\mathbf{2}$ and 3) or n-hexane/diethyl ether (1:1) for $\mathbf{4}$ afforded $\mathbf{2}$ as a brown solid, $\mathbf{3}$ as a beige solid or $\mathbf{4}$ as a pale pink solid, which were finally filtered.

Complex 2. Yield: $0.0590 \mathrm{~g}(30 \%)$. Anal. Calcd for $\mathrm{C}_{35} \mathrm{H}_{20} \mathrm{AuClF}_{10} \mathrm{~N}_{4} \mathrm{O}_{4}$ (982.96): C 42.77, H 2.05, N 5.70. Found: C 42.98, H 1.76, N 5.64. IR: $(\mathrm{NH}): 3049 ;(\mathrm{C}=\mathrm{N})$ : 1592; $\left(\mathrm{C}_{6} \mathrm{~F}_{5}\right)$ : 1509, 967; (cis- $\left.\mathrm{C}_{6} \mathrm{~F}_{5}\right): 812,796 ;\left(\mathrm{ClO}_{4}\right): 1065,622 \mathrm{~cm}^{-1} .{ }^{1} \mathrm{H}$ NMR (400 MHz, $\left.\left.\left(\mathrm{CD}_{3}\right)_{2} \mathrm{CO}\right)\right): \delta 9.12(\mathrm{~m}, 1 \mathrm{H}, 6-\mathrm{H}), 8.64(\mathrm{~m}$, $\left.1 \mathrm{H}, 6{ }^{\prime}-\mathrm{H}\right), 8.46\left(\mathrm{td},{ }^{3} \mathrm{~J}_{\mathrm{H}-\mathrm{H}}=7.7 \mathrm{~Hz},{ }^{4} \mathrm{~J}_{\mathrm{H}-\mathrm{H}}=1.5 \mathrm{~Hz}, 1 \mathrm{H}, 4-\mathrm{H}\right)$, 8.25 (m, 1H, 3-H), 7.98 (m, 4H, 4'-H, 5-H, naphthyl), 7.85 (m, 2H, naphtyl), 7.77 (m, 1H, 3'-H), 7.60 (m, 2H, naphthyl), 7.48 $\left(\mathrm{m}, 1 \mathrm{H}, 5{ }^{\prime}-\mathrm{H}\right), 7.15(\mathrm{~m}, 1 \mathrm{H}$, naphthyl), 5.70, 5.63 (2d, AB system, $\left.{ }^{2} \mathrm{~J}_{\mathrm{AB}}=16.0 \mathrm{~Hz}, 2 \mathrm{H}, \mathrm{CH}_{2}\right), 5.45,5.35(2 \mathrm{~d}, \mathrm{AB}$ system, $\left.{ }^{2} \mathrm{~J}_{\mathrm{AB}}=15.9 \mathrm{~Hz}, 2 \mathrm{H}, \mathrm{CH}_{2}\right)$ ppm. ${ }^{19} \mathrm{~F}$ NMR $(300 \mathrm{MHz}$, $\left.\left(\mathrm{CD}_{3}\right)_{2} \mathrm{CO}\right): \delta-119.7(\mathrm{~m}, 1 \mathrm{~F}, \mathrm{o}-\mathrm{F}),-122.6\left(\mathrm{~d},{ }^{3} \mathrm{~J}_{\mathrm{o}-\mathrm{F}, \mathrm{m}-\mathrm{F}}=25.6 \mathrm{~Hz}\right.$, $1 \mathrm{~F}, \mathrm{o}-\mathrm{F}),-122.9(\mathrm{~m}, 1 \mathrm{~F}, \mathrm{o}-\mathrm{F}),-124.1(\mathrm{~m}, 1 \mathrm{~F}, \mathrm{o}-\mathrm{F}),-157.8\left(\mathrm{t},{ }^{3} \mathrm{~J}_{\mathrm{p}-}\right.$ $\mathrm{F}, \mathrm{m}-\mathrm{F}=23.2,1 \mathrm{~F}, \mathrm{p}-\mathrm{F}),-158.3\left(\mathrm{t},{ }^{3} \mathrm{~J}_{\mathrm{p}-\mathrm{F}, \mathrm{m}-\mathrm{F}}=18.4 \mathrm{~Hz}, 1 \mathrm{~F}, \mathrm{p}-\mathrm{F}\right)$, - 
161.6 (m, 1F, m-F), -162.8 (m, 1F, m-F), -163.7 (m, 1F, m-F), 164.2 (m, 1F, m-F) ppm. ${ }^{13} \mathrm{C}\left\{{ }^{1} \mathrm{H}\right\} \quad \mathrm{NMR} \quad(300 \mathrm{MHz}$, $\left.\left(\mathrm{CD}_{3}\right)_{2} \mathrm{CO}\right): \delta 155.1(\mathrm{~s}, 1 \mathrm{C}, 2-\mathrm{C}), 153.6\left(\mathrm{~s}, 1 \mathrm{C}, 2^{\prime}-\mathrm{C}\right), 152.8(\mathrm{~m}$, 1C, 6-C), 150.1 (s, 1C, 6'-C), 144.6 (s, 1C, 4-C), 139.1 (s, 1C), 134.8 (s, 1C, naphthyl), 133.0 (s, 1C, naphthyl), 130.7 (s, 1C, naphthyl), 128.9 (s, 1C), 128.6 (s, 1C), 128.2 (s, 1C), 127.4 (s, 1C, naphthyl), 124.7 (s, 1C, 5'-C), 124.5 (s, 1C, 3'-C), 122.7 (m, 1C, naphthyl), 122.4 (s, 1C, naphthyl), 61.9 (m, 1C, $\mathrm{CH}_{2}$ ), $59.1\left(\mathrm{~m}, 1 \mathrm{C}, \mathrm{CH}_{2}\right)$ ppm. MS $\left(\mathrm{ESI}^{+}\right): \mathrm{m} / \mathrm{z}(\%) 883$ (100) [M $\left.\mathrm{ClO}_{4}\right]^{+}$.

Complex 3. Yield: $0.1133 \mathrm{~g}(60 \%)$. Anal. Calcd for $\mathrm{C}_{31} \mathrm{H}_{24} \mathrm{AuClF}_{10} \mathrm{~N}_{4} \mathrm{O}_{4}$ (938.95): C 39.65, H 2.58, N 5.97. Found: C 39.61, H 2.82, N 5.75. IR: $(\mathrm{NH}): 3257 ;(\mathrm{C}=\mathrm{N}): 1591 ;\left(\mathrm{C}_{6} \mathrm{~F}_{5}\right)$ : 1508, 961; $\left(\right.$ cis- $\left.\mathrm{C}_{6} \mathrm{~F}_{5}\right): 813,799 ;\left(\mathrm{ClO}_{4}\right): 1065,621 \mathrm{~cm}^{-1} \cdot{ }^{1} \mathrm{H}$ NMR $\left.\left(300 \mathrm{MHz},\left(\mathrm{CD}_{3}\right)_{2} \mathrm{CO}\right)\right): \delta 9.40\left(\mathrm{bs}, 1 \mathrm{H}, \mathrm{NH}_{\mathrm{cy}}\right), 8.83(\mathrm{~d}$, $\left.{ }^{3} \mathrm{~J}_{\mathrm{H}-\mathrm{H}}=5.5 \mathrm{~Hz}, 1 \mathrm{H}, 6-\mathrm{H}\right), 8.31\left(\mathrm{~m}, 2 \mathrm{H}, 4-\mathrm{H}, 6{ }^{\prime}-\mathrm{H}\right), 8.01\left(\mathrm{~d},{ }^{3} \mathrm{~J}_{\mathrm{HH}}\right.$ $=7.5 \mathrm{~Hz}, 1 \mathrm{H}, 3-\mathrm{H}), 7.86\left(\mathrm{~m}, 2 \mathrm{H}, 4^{\prime}-\mathrm{H}, 5-\mathrm{H}\right), 7.63\left(\mathrm{~m}, 1 \mathrm{H}, 3^{\prime}-\right.$ $\mathrm{H}), 7.33(\mathrm{~m}, 1 \mathrm{H}, 5$ '- $\mathrm{H}), 5.71,5.44\left(2 \mathrm{~d}, \mathrm{AB}\right.$ system, ${ }^{2} \mathrm{~J}_{\mathrm{AB}}=15.8$ $\left.\mathrm{Hz}, 2 \mathrm{H}, \mathrm{CH}_{2}\right), 5.33,5.09\left(2 \mathrm{~d}, \mathrm{AB}\right.$ system, ${ }^{2} \mathrm{~J}_{\mathrm{AB}}=16.4 \mathrm{~Hz}, 2 \mathrm{H}$, $\left.\mathrm{CH}_{2}\right), 3.75\left(\mathrm{~m}, 1 \mathrm{H}, \mathrm{CH}_{\mathrm{Cy}}\right), 1.85-0.76(\mathrm{~m}, 10 \mathrm{H}, \mathrm{Cy}) \mathrm{ppm} .{ }^{19} \mathrm{~F}$ NMR (300 MHz, $\left.\left(\mathrm{CD}_{3}\right)_{2} \mathrm{CO}\right): \delta-121.4(\mathrm{~m}, 1 \mathrm{~F}, \mathrm{o}-\mathrm{F}), \delta-123.3$ (m, 2F, o-F), $\delta-124.9(\mathrm{~m}, 1 \mathrm{~F}, \mathrm{o}-\mathrm{F}),-156.5$ (m, 1F, p-F), -158.2 $(\mathrm{m}, 1 \mathrm{~F}, \mathrm{p}-\mathrm{F}),-161.9(\mathrm{~m}, 4 \mathrm{~F}, \mathrm{~m}-\mathrm{F}) \mathrm{ppm} .{ }^{13} \mathrm{C}\left\{{ }^{1} \mathrm{H}\right\}$ NMR $(300$ $\left.\mathrm{MHz},\left(\mathrm{CD}_{3}\right)_{2} \mathrm{CO}\right): \delta 152.5$ (s, 1C, C-6), 149.7, 144.4 (2s, 2C, C4, C-6'), 138.7 (s, 1C), 128.5 (m, 2C), 124.5, 124.2 (2s, 2C, C3', C-5'), $61.7\left(\mathrm{~m}, 1 \mathrm{C}, \mathrm{CH}_{2}\right), 60.8\left(\mathrm{~m}, 1 \mathrm{C}, \mathrm{CH}_{\mathrm{Cy}}\right), 58.3$ (s, 1C, $\mathrm{CH}_{2}$ ), 34.8 (s, Cy), 33.2 (s, Cy), 25.7 (s, Cy), 25.4 (m, Cy) ppm. MS (ESI $\left.{ }^{+}\right): \mathrm{m} / \mathrm{z}(\%) 839(100)\left[\mathrm{M}-\mathrm{ClO}_{4}\right]^{+}$.

Complex 4. Yield: $0.1042 \mathrm{~g}$ (54 \%). Anal. Calcd for $\mathrm{C}_{33} \mathrm{H}_{22} \mathrm{AuClF}_{10} \mathrm{~N}_{4} \mathrm{O}_{4}$ (960.96): $\mathrm{C} 41.25, \mathrm{H} 2.31$, N 5.83. Found: C 41.12, H 2.16, N 5.46. IR: $(\mathrm{NH}): 3050 ;(\mathrm{C}=\mathrm{N}): 1586 ;\left(\mathrm{C}_{6} \mathrm{~F}_{5}\right)$ : 1505, 954; (cis- $\left.\mathrm{C}_{6} \mathrm{~F}_{5}\right): 810,791 ;\left(\mathrm{ClO}_{4}\right): 1071,622 \mathrm{~cm}^{-1} \cdot{ }^{1} \mathrm{H}$ NMR (300 MHz, $\left.\left.\left(\mathrm{CD}_{3}\right)_{2} \mathrm{CO}\right)\right): \delta 8.92\left(\mathrm{~d},{ }^{3} \mathrm{~J}_{\mathrm{HH}}=5.6 \mathrm{~Hz}, 1 \mathrm{H}, 6-\right.$ $\mathrm{H}), 8.37$ (m, 2H, 4-H, 6'-H), $8.08\left(\mathrm{~d},{ }^{3} \mathrm{~J}_{\mathrm{HH}}=7.5 \mathrm{~Hz}, 1 \mathrm{H}, 3-\mathrm{H}\right)$, $7.93\left(\mathrm{~m}, 2 \mathrm{H}, 4^{\prime}-\mathrm{H}, 5-\mathrm{H}\right), 7.74\left(\mathrm{~d},{ }^{3} \mathrm{~J}_{\mathrm{HH}}=7.8 \mathrm{~Hz}, 1 \mathrm{H}, 3^{\prime}-\mathrm{H}\right), 7.38$ (m, 1H, 5'-H), 7.29 (m, 1H, 3''-H), 7.15 (m, 1H, 3''-H), 6.85 (m, $1 \mathrm{H}, 4$ ' '-H), 5.75 y 5.58 (2m, AB system, $\left.2 \mathrm{H}, \mathrm{CH}_{2}\right), 5.58$ and $5.37\left(2 \mathrm{~m}, \mathrm{AB}\right.$ system, $\left.2 \mathrm{H}, \mathrm{CH}_{2}\right), 2.46\left(\mathrm{~s}, 3 \mathrm{H}, \mathrm{CH}_{3}\right), 1.82$ $\left(\mathrm{m}, 3 \mathrm{H}, \mathrm{CH}_{3}\right)$ ppm. ${ }^{19} \mathrm{~F} \mathrm{NMR}\left(400 \mathrm{MHz},\left(\mathrm{CD}_{3}\right)_{2} \mathrm{CO}\right): \delta-120.1$ (m, 1F, o-F), -124.4 (m, 2F, o-F), -125.6 (m, 1F, o-F), -158.6 (m, 1F, p-F), -159.1 (m, 1F, p-F), -162.6 (m, 1F, m-F), - 163.6 $(\mathrm{m}, 2 \mathrm{~F}, \mathrm{~m}-\mathrm{F}),-164.7(\mathrm{~m}, 1 \mathrm{~F}, \mathrm{~m}-\mathrm{F}) \mathrm{ppm} .{ }^{13} \mathrm{C}\left\{{ }^{1} \mathrm{H}\right\}$ NMR $(300$ $\left.\mathrm{MHz},\left(\mathrm{CD}_{3}\right)_{2} \mathrm{CO}\right)$ ): $\delta 151.9$ (m, 1C, 6-C), 149.9 (s, 1C, 6'-C), 144.5 (s, 1C, 4-C), 138.8 (s, 1C, 4'-C), 130.9 (m, 2C, 3' '-C), 129.1 (s, 1C, 5-C), 128.8 (m, 1C, 3-C), 128.4 (m, 1C, 4' '-C), 124.6 y 124.5 (2m, 2C, 3'-C, 5'-C), $59.4\left(\mathrm{~m}, 1 \mathrm{C}, \mathrm{CH}_{2}\right), 58.3$ (m, 1C, $\left.\mathrm{CH}_{2}\right), 18.6\left(\mathrm{~m}, 1 \mathrm{C}, \mathrm{CH}_{3}\right), 18.1\left(\mathrm{~m}, 1 \mathrm{C}, \mathrm{CH}_{3}\right)$ ppm. MS $\left(\mathrm{ESI}^{+}\right): \mathrm{m} / \mathrm{z}(\%) 861(100)\left[\mathrm{M}-\mathrm{ClO}_{4}\right]^{+}$.

\section{Cell culture}

Jurkat (leukaemia) and MiaPaca2 (pancreatic carcinoma) cell lines were maintained in RPMI 1640, while A549 (lung carcinoma) were grown in DMEM (Dulbecco's Modified Eagle's Medium). Both media were supplemented with $5 \%$ fetal bovine serum (FBS), $200 \mathrm{U} / \mathrm{ml}$ penicillin, $100 \mu \mathrm{g} / \mathrm{ml}$ streptomycin and $2 \mathrm{mM}$ L-glutamine. Medium for A549 cells was also supplemented with $2.2 \mathrm{~g} / 1 \quad \mathrm{Na}_{2} \mathrm{CO}_{3}, 100 \mu \mathrm{g} / \mathrm{ml}$ piruvate and $5 \mathrm{ml}$ non-essential amino acids (Invitrogen). Cultures were maintained in a humidified atmosphere of $95 \%$ air $/ 5 \% \mathrm{CO}_{2}$ at $37^{\circ} \mathrm{C}$.

\section{Cytotoxicity assay by MTT}

The MTT assay was used to determine cell viability as an indicator for cells sensitivity to the complexes. Exponentially growing cells were seeded at a density of approximately $1 \times 10^{5}$ cells $/ \mathrm{ml}$ (A549, MiaPaca2) or $3 \times 10^{5}$ cells $/ \mathrm{ml}$ (Jurkat), in a 96well flat-bottomed microplate and $24 \mathrm{~h}$ later they were incubated for $24 \mathrm{~h}$ with the compounds. The complexes were dissolved in DMSO and tested in concentrations ranging from 0.5 to $25 \mu \mathrm{M}$ and in quadruplicate. Cells were incubated with our compounds for $24 \mathrm{~h}$ at $37{ }^{\circ} \mathrm{C} .10 \mu \mathrm{l}$ of MTT $(5 \mathrm{mg} / \mathrm{ml})$ was added and plates were incubated for $1-3 \mathrm{~h}$ at $37^{\circ} \mathrm{C}$. Finally, 100 $\mu 1 /$ well ${ }^{\text {}} \mathrm{PrOH}(0.05 \mathrm{M} \mathrm{HCl})$ was added. The optical density was measured at $490 \mathrm{~nm}$ using a 96-well multiscanner autoreader (ELISA). The $\mathrm{IC}_{50}$ was calculated by non-linear regression analysis using Origin software (Origin Software, Electronic Arts, Redwood City, California, USA).

\section{Crystal Structure Determinations}

Crystals were mounted in inert oil on glass fibers and transferred to the cold gas stream of an APEX SMART diffractometer equipped with a low-temperature attachment. Data were collected using monochromated Mo K $\alpha$ radiation $(\lambda=0.71073 \AA)$. Scan type $\omega$. Absorption correction based on multiple scans were applied with the program SADABS. The structures were solved by direct methods and refined on $F^{2}$ using the program SHELXL-97. ${ }^{86}$ Hydrogen atoms were included using a riding model. Further details of the data collection and refinement are shown in Table 2. CCDC 1039443-1039446. 
Table 2 Details of Data Collection and Structure Refinement for Complexes $\mathbf{1}-\mathbf{4}$.

\begin{tabular}{|c|c|c|c|c|}
\hline Compound & 1 & $2 \cdot\left(\mathrm{CH}_{3}\right)_{2} \mathrm{CO}$ & $\mathbf{3} \cdot\left(\mathrm{CH}_{3}\right)_{2} \mathrm{CO}$ & $\mathbf{4} \cdot\left(\mathrm{CH}_{3}\right)_{2} \mathrm{CO}$ \\
\hline Chemical Formula & $\mathrm{C}_{24} \mathrm{H}_{13} \mathrm{AuClF}_{10} \mathrm{~N}_{3} \mathrm{O}_{4}$ & $\mathrm{C}_{38} \mathrm{H}_{26} \mathrm{AuClF}_{10} \mathrm{~N}_{4} \mathrm{O}_{5}$ & $\mathrm{C}_{34} \mathrm{H}_{30} \mathrm{AuClF}_{10} \mathrm{~N}_{4} \mathrm{O}_{5}$ & $\mathrm{C}_{36} \mathrm{H}_{28} \mathrm{AuClF}_{10} \mathrm{~N}_{4} \mathrm{O}_{5}$ \\
\hline Cryst habit & Colorless prism & Colorless prism & Colorless rhomboid prism & Colorless tablet \\
\hline Cryst size/ mm & $0.24 \times 0.16 \times 0.06$ & $0.24 \times 0.10 \times 0.08$ & $0.16 \times 0.16 \times 0.16$ & $0.16 \times 0.08 \times 0.08$ \\
\hline Cryst system & Monoclinic & Triclinic & Triclinic & Triclinic \\
\hline Space group & $\mathrm{P} 2{ }_{1} / \mathrm{c}$ & P-1 & P-1 & P-1 \\
\hline$a / \AA$ & $15.629(2)$ & $8.1961(16)$ & $10.010(2)$ & $10.500(2)$ \\
\hline$c / \AA$ & $16.354(2)$ & $20.475(4)$ & $13.960(3)$ & $13.812(3)$ \\
\hline$\alpha / d e g$ & - & $97.15(3)$ & $84.66(3)$ & $80.76(3)$ \\
\hline$\beta / \mathrm{deg}$ & $101.680(2)$ & 101.31(3) & $70.66(3)$ & $69.01(3)$ \\
\hline$\gamma / \mathrm{deg}$ & - & 101.21(3) & $79.31(3)$ & $77.33(3)$ \\
\hline$U / \AA^{3}$ & $2466.4(6)$ & $1808.6(6)$ & $1780.5(7)$ & $1777.1(6)$ \\
\hline $\boldsymbol{Z}$ & 4 & 2 & 2 & 2 \\
\hline$M$ & 829.79 & 1041.04 & 997.04 & 1019.04 \\
\hline$F(000)$ & 1584 & 1016 & 976 & 996 \\
\hline $\mathbf{T} /{ }^{\circ} \mathbf{C}$ & $-100(2)$ & $-100(2)$ & $-100(2)$ & $-100(2)$ \\
\hline $2 \theta_{\max } /^{\circ}$ & 60 & 60 & 60 & 60 \\
\hline$\mu(\mathrm{Mo}-K \alpha) / \mathrm{mm}^{-1}$ & 6.190 & 4.245 & 4.307 & 4.318 \\
\hline Transmission & $0.7077-0.3181$ & $0.7276-0.4290$ & $0.5457-0.5457$ & $0.7239-0.5450$ \\
\hline no. of reflns measd & 19320 & 12983 & 14758 & 10778 \\
\hline no. of unique refns. & 4838 & 6962 & 6936 & 5973 \\
\hline$R_{\text {int }}$ & 0.0339 & 0.0403 & 0.0153 & 0.0183 \\
\hline$R(F>4 \sigma(F))$ & 0.0236 & 0.0515 & 0.0199 & 0.0224 \\
\hline$R_{w}(F 2$, all refl. $)$ & 0.0560 & 0.1178 & 0.0500 & 0.0538 \\
\hline No. of reflns used & 4838 & 6962 & 6936 & 5973 \\
\hline No. of params & 388 & 534 & 478 & 498 \\
\hline $\max . / \min \Delta \rho / e A^{-3}$ & $0.826 /-0.850$ & $2.419 /-3.532$ & $1.364 /-0.597$ & $1.001 /-0.524$ \\
\hline
\end{tabular}

\section{General procedure for Au-catalyzed synthesis of phenol derivative 6.}

Gold complex $1(0.83 \mathrm{mg}, 0.001 \mathrm{mmol})$ and furan $5(30.3 \mathrm{mg}$, $0.1 \mathrm{mmol})$ are solved in $\mathrm{CDCl}_{3}(0.5 \mathrm{ml})$ in a test tube. The resulting mixture was stirred at room temperature until the reaction was completed as monitored by thin-layer chromatography. The yield of the reaction is given by ${ }^{1} \mathrm{H}$ NMR.

General procedure for Au-catalyzed three-component synthesis of propargylamines 12-14.

A mixture of gold complex 1 (4.1 $\mathrm{mg}, 0.005 \mathrm{mmol})$, benzaldehyde 7 (51 $\mu \mathrm{l}, 0.5 \mathrm{mmol})$, amine 8-10 (0.55 $\mathrm{mmol})$, phenylacetylene 11 ( $84 \mu \mathrm{l}, 0.75 \mathrm{mmol})$ was added under solvent-free conditions. The resulting reaction mixture was stirred at $40{ }^{\circ} \mathrm{C}$ for 24 h. The d.r. and the yields of the reaction are given by ${ }^{1} \mathrm{H}$ NMR using dimethylfumarate as internal standard.
General procedure for Au-catalyzed three-component synthesis of indolizines 18 and 19 under solvent-free conditions.

A mixture of gold complex 1 (4.1 $\mathrm{mg}, 0.005 \mathrm{mmol})$, pyridine-2carboxaldehyde $15(48 \mu \mathrm{l}, 0.5 \mathrm{mmol})$ and amine 16 or 17 (1.1 mmol), phenylacetylene $11(67 \mu 1,1.2 \mathrm{mmol})$ was added successively at $60{ }^{\circ} \mathrm{C}$. The resulting mixture was stirred at $60{ }^{\circ} \mathrm{C}$ until the reaction was completed as monitored by thin-layer chromatography. The yield of the reaction is given by ${ }^{1} \mathrm{H}$ NMR using dimethylfumarate as internal standard.

\section{Conclusions}

A new fluxional amine gold(III) complex has been synthesised and characterised. Interestingly, its dynamic behaviour in solution has been studied and, in solid state, the molecule is chiral with an asymmetric quaternary amine nitrogen 
coordinated to gold(III). Reactions of this complex with isocyanides led unprecedented bidentate $\mathrm{C}^{\wedge} \mathrm{N}$ gold(III) acyclic carbene derivatives. Antitumor properties of these complexes have been tested in vitro against three tumour human cell lines, Jurkat (T-cell leukaemia), MiaPaca2 (pancreatic carcinoma) and A549 (lung carcinoma), showing excellent cytotoxic activity in very tough cell lines such as MiaPaca2 and A549, compared with cisplatin and with other gold(III) derivatives. Taking advantage of the fluxional behaviour of the amine complex, its catalytic properties have been tested in several model reactions with formation of $\mathrm{C}-\mathrm{C}$ and $\mathrm{C}-\mathrm{N}$ bonds. The complex showed excellent activity with total conversions, without the presence of a co-catalyst, and with a low catalyst loading. These results can be seen as new examples of the versatile behaviour of well-defined functionalised amine gold(III) complexes. We believe that with these three benchmark examples we have demonstrated the strong capacity of our complex to act as an efficient catalyst in a variety of different reactions. Additional catalytic studies are actually ongoing in our laboratory and will be reported in due course. In summary, a new type of gold(III) species with functionalised amines are proposed as excellent synthons for the preparation of novel gold(III) complexes with bidentate acyclic carbenes, which show excellent cytotoxic activity, and also as outstanding well-defined catalysts for several organic transformations, including the synthesis of products of biological interest.

\section{Acknowledgements}

Authors thank the Ministerio de Economía y Competitividad (MINECO/FEDER CTQ2013-48635-C2-1-P) and DGA-FSE (E77) for financial support. We also acknowledged Dr. Isabel Marzo for her help in the cell viability tests.

\section{Notes and references}

${ }^{a}$ Departamento de Química Inorgánica, Instituto de Síntesis Química y Catálisis Homogénea (ISQCH), Universidad de Zaragoza-CSIC, E-50009 Zaragoza, Spain. E-mail: gimeno@unizar.es; Fax: +34 976761187; Tel: +34976762291 and dvilla@unizar.es; Tel: +34976761183.

${ }^{b}$ Departamento de Química Orgánica, Instituto de Síntesis Química y Catálisis Homogénea (ISQCH), Universidad de Zaragoza-CSIC, E-50009 Zaragoza, Spain.

$\dagger$ Footnotes should appear here. These might include comments relevant to but not central to the matter under discussion, limited experimental and spectral data, and crystallographic data.

Electronic Supplementary Information (ESI) available: [details of any supplementary information available should be included here]. See DOI: $10.1039 / \mathrm{b} 000000 \mathrm{x} /$

1 W. Henderson, Adv. Organomet. Chem., 2006, 54, 207-265.

2 A. Casini, Ch. Hartinger, Ch. Gabbiani, E. Mini, P. J. Dyson, B. K. Keppler and L. Messori, J. Inorg. Biochem., 2008, 102, 564-575.

3 C. Gabbiani, G. Mastrobuoni, F. Sorrentino, B. Dani, M. P. Rigobello, A. Bindoli, M. A. Cinellu, G. Pieraccini, L. Messori and A. Casini, Med. Chem. Commun., 2011, 2, 50-54.
4 J-J. Zhang, R. W.-Y. Sun and C.-M. Che, Chem. Commun., 2012, 48, 3388-3390.

5 B. Bertrand and A. Casini, Dalton Trans., 2014, 43, 4209-4219.

6 L. Ronconi, C. Marzano, P. Zanello, M. Corsini, G. Miolo, C. Macca, A. Trevisan and D. Fregona, J. Med. Chem., 2006, 49, 1648-1657.

7 J.-J. Zhang, W. Lu, R. W.-Y. Sun and C.-M. Che, Angew. Chem. Int. Ed., 2012, 51, 4882-4886.

8 V. W-W. Yam and E. C.-C. Cheng, Top. Curr. Chem., 2007, 281, 269-309.

9 C. Bronner and O. S. Wenger, Dalton Trans., 2011, 40, 12409-12420.

10 V. K.-M. Au, K. M.-C. Wong, N. Zhu and V. W-W. Yam, Chem. Eur. J., 2011, 17, $130-142$.

11 M. E. Hanham, Gold Bull., 2011, 44, 43 - 47.

12 N. Krause and C. Winter, Chem. Rev., 2011, 111, 1994-2009.

13 K. J. Kilpin, B. P. Jarman, W. Henderson and B. K. Nicholson, Appl. Organometal. Chem., 2011, 25, 810-814.

14 J. Wimberg, S. Meyer, S. Dechert and F. Meyer, Organometallics, 2012, 31, 5025-5033.

15 H.-M. Ko, K. K.-Y. Kung, J.-F. Cui and M.-K. Wong, Chem. Commun. 2013, 49, 8869-8871.

16 S. Díez-Gonzalez, N. Marion and S. P. Nolan, Chem. Rev. 2009, 109, 3612-3676.

17 S. P. Nolan, Acc. Chem. Res., 2011, 44, 91-100.

18 L. Oehninger, R. Rubbiani and I. Ott, Dalton Trans., 2013, 42, 32693284.

19 R. Visbal and M. C. Gimeno, Chem. Soc. Rev., 2014, 43, 3551-3574.

20 C. Bartolomé, Z. Ramiro, P. Pérez-Galán, C. Bour, M. Raducan, A. M. Echavarren and P. Espinet, Inorg. Chem., 2008, 47, 11391-11397.

21 A. S. K. Hashmi, T. Hengst, C. Lothschütz and F. Rominger, Adv. Synth. Catal., 2010, 352, 1315-1337.

22 C. Bartolomé, Z. Ramiro, D. García-Cuadrado, P. Pérez-Galán, M. Raducan, C. Bour, A. M. Echavarren and P. Espinet, Organometallics, 2010, 29, 951-956.

23 C. Bartolomé, D. García-Cuadrado, Z. Ramiro and P. Espinet, Inorg. Chem., 2010, 49, 9758-9764.

24 Y. M. Wang, C. N. Kuzniewski, V. Rauniyar, C. Hoong and F. D. Toste, J. Am. Chem. Soc., 2011, 133, 12972-12975.

25 L. G. M. Slaughter, ACS Catal., 2012, 2, 1802-1816.

26 M. C. Blanco Jaimes, C. R. N. Böhling, J. M. Serrano-Becerra and A. S. K. Hashmi, Angew. Chem. Int. Ed., 2013, 52, 7963-7966.

27 R. L. White-Morris, M. M. Olmstead, F. Jiang, D. S. Tinti and A. L Balch, J. Am. Chem. Soc., 2002, 124, 2327-2336.

28 D. Rios, M. M. Olmstead and A. L. Balch, Dalton Trans., 2008, 4157-4164.

29 C. Bartolomé, M. Carrasco-Rando, S. Coco, C. Cordovilla, J. M. Martín-Alvarez and P. Espinet, Inorg. Chem., 2008, 47, 1616-1624.

30 D. Rios, M. M. Olmstead and A. L. Balch, Inorg. Chem., 2009, 48, 5279-5287.

31 G. Minghetti and F. Bonati, J. Organomet. Chem., 1973, 54, C62-C63.

32 G. Minghetti, F. Bonati and G. Banditelli, Inorg. Chem., 1976, 15, $1718-1720$.

33 R. Usón, A. Laguna, J. Vicente, J. García, B. Bergareche and P. Brun, Inorg. Chim. Acta, 1978, 28, 237-243. 
34 R. Usón, A. Laguna and M. D. Villacampa, Inorg. Chim. Acta, 1984, 81, 25-31.

35 R. Usón, A. Laguna, M. D. Villacampa, P. G. Jones and G. M. Sheldrick, J. Chem. Soc., Dalton Trans., 1984, 2035-2038.

36 O. Crespo, M. C. Gimeno, A. Laguna, S. Montanel-Pérez and M. D Villacampa, Organometallics, 2012, 31, 5520-5526.

37 A. S. K. Hashmi, Chem. Rev., 2007, 107, 3180-3211.

38 A. S. K. Hashmi and G. J. Hutchings, Angew. Chem. Int. Ed., 2006, 45, 7896-7936.

39 A. S. K. Hashmi, J. P. Weyrauch, M. Rudolph and E. Kuperjovic, Angew. Chem. Int. Ed. Eng., 2004, 43, 6545-6547.

40 C. González-Arellano, A. Corma, M. Iglesias and F. Sánchez, Chem. Commun., 2005, 1990-1992.

41 M. Pažický, A. Loos, M. J. Ferreira, D. Serra, N. Vinokurov, F. Rominger, C. Jäkel, A. S. K. Hashmi and M. Limbach, Organometallics, 2010, 29, 4448-4458.

42 N. P. Mankad and F. D. Toste, J. Am. Chem. Soc., 2010, 132, 12859-12861.

43 M. K. Samantaray, C. Dash, M. M. Shaikh, K. Pang, R. J. Butcher and P. Ghosh, Inorg. Chem., 2011, 50, 1840-1848.

44 E. Tomás-Mendivil, P. Y. Toullec, J. Díez, S. Conejero, V. Michelet and V. Cadierno, Org. Lett., 2012, 14, 2520-2523.

45 M. Muuronen, J. E. Perea-Buceta, M. Nieger, M. Patzschke and J. Helaja, Organometallics, 2012, 31, 4320-4330.

46 P. Oña-Burgos, I. Fernández, L. Roces, L. Torre Fernández, S. García-Granda and F. López-Ortiz, Organometallics, 2009, 28, 17391747.

47 K. K. Y. Kung, G. L. Li, L. Zou, H. C. Chong, Y. C. Leung, K. H. Wong, V. K. Y. Lo, C. M. Che and M. K. Wong, Org. Biomol. Chem., 2012, 10, 925-930.

48 K. K. Y. Kung, V. K. Y. Lo, H. M. Ko, G. L. Li, P. Y. Chan, K. C. Leung, Z. Zhou, M. Z. Wang, C. M. Che and M. K. Wong, Adv. Synth. Catal., 2013, 355, 2055-2070.

49 V. K. Y. Lo, Y. G. Liu, M.-K. Wong and C. M. Che, Org. Lett., 2006, 8, 1529-1532.

50 R. Casado, M. Contel, M. Laguna, P. Romero and S. Sanz, J. Am. Chem. Soc., 2003, 125, 11925-11935.

51 D. Aguilar, M. Contel, R. Navarro and E. P. Urriolabeitia, Organometallics, 2007, 26, 4604-4611.

52 L. Cao, M. C. Jennings and R. J. Pudddephatt, Inorg. Chem., 2007, 46, 1361-1368.

53 A. P. Shaw, M. K. Ghosh, K. W. Törnroos, D. S. Wragg, M. Tilset, O. Swang, R. H. Heyn and S. Jakobsen, Organometallics, 2012, 31, 7093-7100.

54 W. T. Robinson and E. Sinn, J. Chem. Soc. Dalton Trans., 1975, 726731.

55 Z. D. Hudson, C. D. Sanghvi, M. A. Rhine, J. J. Ng, S. D. Bunge, K. I. Hardcastle, M. R. Saadein, C. E. MacBeth and J. F. Eichler, Dalton Trans., 2009, 7473-7480.

56 C. Topf, C. Hirtenlehner, M. Zabel, M. List, M. Fleck and U. Monkowius, Organometallics, 2011, 30, 2755-2764.

57 O. Crespo, M. C. Gimeno, P. G. Jones, A. Laguna, M. Naranjo and M. D. Villacampa, Eur. J. Inorg. Chem., 2008, 5408-5417.

58 R. W. Y. Sun and C. M. Che., Coord. Chem. Rev., 2009, 253, 16821691.
59 A. Casini, M. C. Diawara, R. Scopelliti, S. M. Zakeeruddin, M. Grätzel and P. J. Dyson, Dalton Trans. 2010, 39, 2239-2245.

60 L. Messori, G. Marcon, M. A. Cinellu, M. Coronnello, E. Mini, C. Gabbiani and P. Orioli, Bioorg. Med. Chem., 2004, 12, 6039-6043.

61 M. Coronnello, E. Mini, B. Caciagli, M. A. Cinellu, A. Bindoli, C. Gabbiani and L. Messori, J. Med. Chem., 2005, 48, 6761-6765.

62 A. Casini, G. Kelter, C. Gabbiani, M. A. Cinellu, G. Minguetti, D. Fregona, H. H. Fiebig and L. Messori, J. Biol. Inorg. Chem., 2009, 14, 1139-1149.

63 M. C. Alley, D. A. Scudiero, A. Monks, M. L. Hursey, M. J. Czerwinski, D. L. Fine, B. J. Abbott, J. G. Mayo, R. H. Shoemaker and M. R. Boyd, Cancer Res., 1988, 48, 589-601.

64 D. Garayalde and C. Nevado, Beilstein J. Org. Chem., 2011, 7, 767780.

65 D. J. Gorin, B. D. Sherry and F. D. Toste, Chem. Rev., 2008, 108, 3351-3378.

66 A. Arcadi, Chem. Rev., 2008, 108, 3266-3325.

67 A. Corma, A. Leyva-Pérez and M. J. Sabater, Chem. Rev., 2011, 111, 1657-1712.

68 E. Jiménez-Núñez and A. M. Echavarren, Chem. Rev., 2008, 108, 3326-3350.

69 M. C. Blanco, Catalysis in Modern Supramolecular Gold Chemistry: gold-Metal Interactions and Applications, Ed. A. Laguna, WileyVCH Verlag, Weinheim, 2008, 429-494.

70 A. S. K. Hashmi and D. F. Toste, D. F. (Eds), Modern Gold Catalysed Synthesis Wyley-VCH Verlag, Weinheim, 2009.

71 A. S. K. Hashmi, T. M. Frost and J. W. Bats, J. Am. Chem. Soc., 2000, 122, 11553-11554.

72 A. S. K. Hashmi, T. M. Frost, J. W. Bats, Org. Lett. 2001, 3, 37693771.

73 S. Carrettin, M. C. Blanco, A. Corma, A. S. K. Hashmi, Adv. Synth. Catal. 2006, 348, 1283-1288.

74 A. S. K. Hashmi, M. Rudolph, H.-U. Siehl, M. Tanaka, J. W. Bats, W. Frey, Chem. Eur. J. 2008, 14, 3703-3708.

75 V. A. Peshkov, O. P. Pereshivko and E. V. Van der Eycken, Chem. Soc. Rev., 2012, 41, 3790-3807.

76 C. Wei and C.-J. Li, J. Am. Chem. Soc., 2003, 125, 9584-9585.

77 J. Zhu and H. Bienaymé, Eds. Multicomponent Reactions, WileyVCH: Weinheim, 2005.

78 Y. Liu, Y. Arkivoc, 2014, (i), 1-20.

79 For a recent review, see: G. S. Singh and E. E. Mmatli, Eur. J. Med. Chem., 2011, 46, 5237-5257.

80 I. V. Seregin and V. Gevorgyan, J. Am. Chem. Soc., 2006, 128, 12050-12051.

81 T. Schwier, A. W. Sromek, D. M. L. Yap, D. Chernyak and V. Gevorgyan, J. Am. Chem. Soc., 2007, 129, 9868-9878.

82 B. Yan and Y. Liu, Org. Lett., 2007, 9, 4323-4326.

83 I. V. Seregin, A. W. Schammel and V. Gevorgyan, Tetrahedron, 2008, 64, 6876-6883.

84 G. R. Fulmer, A. J. M. Miller, N. H. Sherden, H. E. Gottlieb, A. Nudelman, B. M. Stoltz, J. E. Bercaw and K. I. Goldberg, Organometallics, 2010, 29, 2176-2179.

85 R. Usón, A. Laguna and M. L. Arrese, Synth. React. Inorg. Met-Org. Chem., 1984, 14, 557-567.

86 G. M. Sheldrick, Acta Crystallogr., 2008, A64, 112-122. 